\title{
Experimental Study on Mechanical Properties of Q345 Steel after High Temperature Cooling
}

\author{
Fei Zhu, Yu Zhang, Chuntao Zhang \\ School of Civil Engineering and Architecture, Southwest University of Science and Technology, Mianyang, China \\ Email: 13955728189@163.com
}

How to cite this paper: Zhu, F., Zhang, Y. and Zhang, C.T. (2020) Experimental Study on Mechanical Properties of Q345 Steel after High Temperature Cooling. World Journal of Engineering and Technology, 8, 257-265.

https://doi.org/10.4236/wjet.2020.83021

Received: June 15, 2020

Accepted: July 14, 2020

Published: July 17, 2020

Copyright $\odot 2020$ by author(s) and Scientific Research Publishing Inc. This work is licensed under the Creative Commons Attribution International License (CC BY 4.0).

http://creativecommons.org/licenses/by/4.0/

\section{c) (i) Open Access}

\begin{abstract}
Because of its advantages of light weight, high strength and convenient construction, steel structure has gradually become the first choice for large-span and high-rise structures. The use of high strength steel in building engineering can reduce the section size of components and the weight of the structure, thus increasing the building area. But steel is not fire-resistant, when the temperature reaches $600^{\circ} \mathrm{C}$, steel loses most of the stiffness and strength. Therefore, it is of great significance to study the fire resistance of steel structures, and the mechanical properties of steel structures at high temperature are the foundation of the fire resistance research. The mechanical properties of steel after high temperature are the basis for the safety assessment of steel structure after fire. Therefore, this paper studies the mechanical properties of Q345 steel after high temperature cooling.
\end{abstract}

\section{Keywords}

Q345 Steel, High Temperature Natural Cooling, Mechanical Properties

\section{Introduction}

With the increasing number of fire accidents around the world, the study of high temperature mechanical properties of steel is a hot topic. The high temperature properties of materials include the properties of materials at high temperature and after high temperature (cooling). At present, the research on high temperature properties of steel mainly focuses on the mechanical properties under high temperature. This paper studies the influence of mechanical properties such as the flexural strength of refractory steel columns [1]. He conducted an experimental study on the mechanical properties of Q235 steel, the most commonly used steel structure building, at high temperature. He obtained the law of the variation of various mechanical properties of Q235 steel with temperature, es- 
tablished its mechanical model with temperature change, and used this model to analyze and study the reaction of steel frame model in fire [2]. He believed that the determination of mechanical properties of steel at high temperature is an important part of the analysis of fire resistance of steel structure, so a series of high temperature material properties tests of steel were carried out. Based on the analysis of the test results, a convenient high temperature material property model of steel tri-fold line was put forward to carry out the structural fire reaction more accurately Should analysis laid the foundation [3]. He conducted material performance tests on Q345 steel commonly used in construction steel structures in China at high temperature. According to the test results, the high-temperature steel model that can be used for theoretical analysis was obtained and compared with the high-temperature steel model recommended by other countries [4]. They are introduced the properties of Q235 steel under different stress path-temperature test, in order to study the effect of stress and temperature history on the steel strain. Through regression analysis of experimental data, obtained the different path of Q235 steel under stress and temperature stress, the constitutive relations between and among temperature, strain and Q235 steel were studied through the dead load and raising temperature and natural cooling to room temperature of material mechanical properties, and are compared with those of the previous research results [5]. In China, the mechanical properties of steel reinforcement used in construction have been studied at high temperature. Tongji University has also conducted material properties test at high temperature for Q235 steel, and they all proposed their own mechanical properties models at high temperature [6].

Although the above scholars have done a lot of research on the mechanical properties of steel at high temperature, the strength grade, chemical composition and cooling mode of steel all have obvious differences in the mechanical properties after high temperature. Therefore, the tensile test of Q345 steel naturally cooled at room temperature $\left(20^{\circ} \mathrm{C}, 250^{\circ} \mathrm{C}, 500^{\circ} \mathrm{C}\right.$ and $\left.750^{\circ} \mathrm{C}\right)$ was conducted in this paper to study the variation rule of mechanical properties parameters of Q345 steel naturally cooled at high temperature, so as to provide a basis for the evaluation and reinforcement of Q345 steel building naturally cooled after fire.

\section{Experimental Investigation}

\subsection{Specimen Design}

Figure 1 shows the shape and size of the Specimens.

\subsection{Test Equipment}

Figure 2 shows the test equipment. This test was completed in Sichuan Province by engineering material and structure impact. WAW-300B electro-hydraulic servo universal testing machine was selected for the test, as shown in Figure 2. The equipment was mainly composed of host system, control system and data output system, and the maximum dynamic load was $\pm 300 \mathrm{kN}$. The high temper- 
ature heating device uses a resistance furnace with the highest temperature up to $1000^{\circ} \mathrm{C}$. The steel specimens are subjected to normal temperature, $250^{\circ} \mathrm{C}, 500^{\circ} \mathrm{C}$ and $700^{\circ} \mathrm{C}$ at the preset temperature, and then placed in a high temperature furnace for $5 \mathrm{~h}$, and then taken out for natural cooling in the atmosphere [7]-[13].

\subsection{Test Procedure}

The test is a unidirectional tensile test of Q345B steel plate at different temperatures. The test temperature includes room temperature, $250^{\circ} \mathrm{C}, 500^{\circ} \mathrm{C}$ and $750^{\circ} \mathrm{C}$. In the process of high temperature treatment, the heating rate is $9^{\circ} \mathrm{C}$ $11^{\circ} \mathrm{C} / \mathrm{min}$. When the test piece reaches the specified temperature, the constant temperature is $5 \mathrm{~h}$ to ensure that the test piece is uniformly heated. After heating, open the furnace door and let it stand for 24 hours, making it naturally cool to room temperature. The main data obtained from the test include: stress-strain diagram, yield strength, ultimate strength, elastic modulus, elongation.

\section{Experimental Results}

\subsection{Apparent Characteristics}

By observing the fracture of the test specimen, it can be found that: after the same test temperature, the fracture of the specimen shows basically the same surface characteristics.

1) The temperature is less than or equal to $250^{\circ} \mathrm{C}$, and the fracture color has no obvious change compared with normal temperature. The specimen has obvious necking phenomenon when approaching failure.

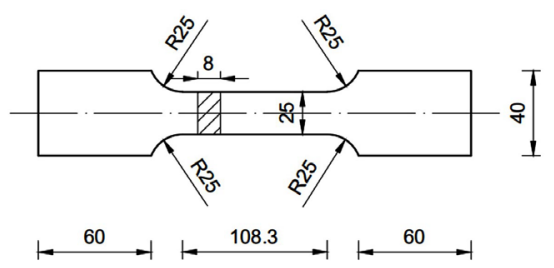

Figure 1. Specimens of Q345 (mm).

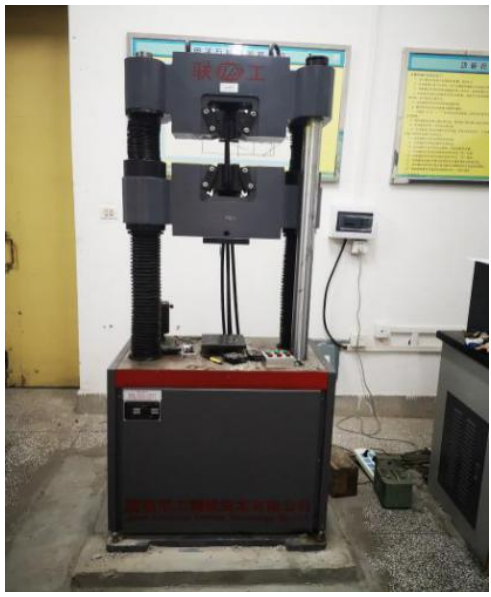

Figure 2. Electro-hydraulic Servo Universal Tester. 
2) The temperature is between $250^{\circ} \mathrm{C}$ and $300^{\circ} \mathrm{C}$, the fracture is golden yellow, and the cooling color does not change significantly with the temperature. The specimen has obvious necking phenomenon when approaching failure.

3) When the temperature is $500^{\circ} \mathrm{C}$, the fracture color is light black, and gradually becomes dim with the temperature cooling. The specimen has obvious necking phenomenon when approaching failure.

4) When the temperature is $750^{\circ} \mathrm{C}$, the fracture is black, and the black gradually deepens as the temperature rises. The specimen shows plastic flow and high elongation at failure.

\subsection{Stress-Strain Relationships}

Figure 3 shows the stress-strain curve obtained by the tensile test at room temperature. It has an obvious yield platform with a yield strength of $276.5 \mathrm{Mpa}$ and ultimate strength of $374.5 \mathrm{Mpa}$. Then the tensile test of Q345 steel cooled at $250^{\circ} \mathrm{C}, 500^{\circ} \mathrm{C}$ and $750^{\circ} \mathrm{C}$ was carried out, and the stress-strain curve of the steel was obtained as shown in Figure 4.

\subsection{Mechanical Performance Parameters}

Table 1 lists the yield strength, tensile strength, flexural ratio and elongation of steel at high temperature. As can be seen from Table 1, with the increase of steel's heating temperature, the yield strength, flexural ratio and elongation of steel after high temperature generally increase gradually, while the tensile strength decreases gradually.

Table 1. Mechanical parameters of Q345 steel after high temperature cooling.

\begin{tabular}{|c|c|c|c|c|c|c|}
\hline Condition & Number & $\begin{array}{c}\text { Yield } \\
\text { strength (MPa) }\end{array}$ & $\begin{array}{c}\text { Tensile } \\
\text { strength }(\mathrm{MPa})\end{array}$ & $\begin{array}{l}\text { Yield } \\
\text { ratio }\end{array}$ & $\begin{array}{l}\text { Elasticity } \\
\text { modulus }\end{array}$ & $\begin{array}{c}\text { Elongation } \\
(\%)\end{array}$ \\
\hline \multirow{4}{*}{$20^{\circ} \mathrm{C}$} & TS250 & 352.54 & 497.31 & 0.71 & 217.456 & 29.03 \\
\hline & TS250 & 347.01 & 496.64 & 0.70 & 218.364 & 29.19 \\
\hline & TS250 & 354.44 & 498.35 & 0.71 & $220 . .395$ & 29.03 \\
\hline & The mean & 351.33 & 497.43 & 0.71 & 218.738 & 29.08 \\
\hline \multirow{4}{*}{$250^{\circ} \mathrm{C}$} & TS250 & 359.65 & 488.60 & 0.74 & 221.175 & 29.84 \\
\hline & TS250 & 362.38 & 495.50 & 0.73 & 220.173 & 30.81 \\
\hline & TS250 & 361.92 & 493.28 & 0.73 & 215.862 & 29.84 \\
\hline & The mean & 361.31 & 492.46 & 0.73 & 219.071 & 30.16 \\
\hline \multirow{4}{*}{$500^{\circ} \mathrm{C}$} & TS500 & 369.98 & 486.07 & 0.76 & 215.081 & 30.65 \\
\hline & TS500 & 366.11 & 486.29 & 0.75 & 216.156 & 30.65 \\
\hline & TS500 & 370.20 & 489.01 & 0.76 & 218.168 & 30.65 \\
\hline & The mean & 368.76 & 487.12 & 0.76 & 216.468 & 30.65 \\
\hline \multirow{4}{*}{$750^{\circ} \mathrm{C}$} & TS750 & 291.33 & 391.02 & 0.75 & 221.522 & 32.58 \\
\hline & TS750 & 294.13 & 397.20 & 0.74 & 221.475 & 33.71 \\
\hline & TS750 & 293.49 & 395.13 & 0.74 & 219.288 & 33.23 \\
\hline & The mean & 292.98 & 394.45 & 0.74 & 220.762 & 33.17 \\
\hline
\end{tabular}


$20^{\circ} \mathrm{C}$

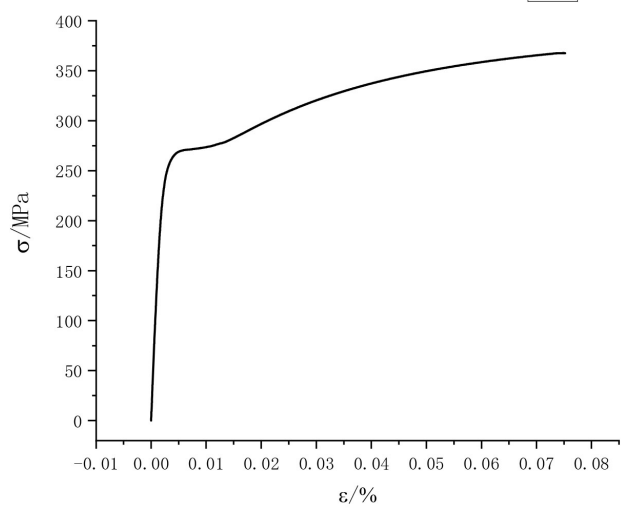

Figure 3. Stress-strain curve of Q345 steel at room temperature.
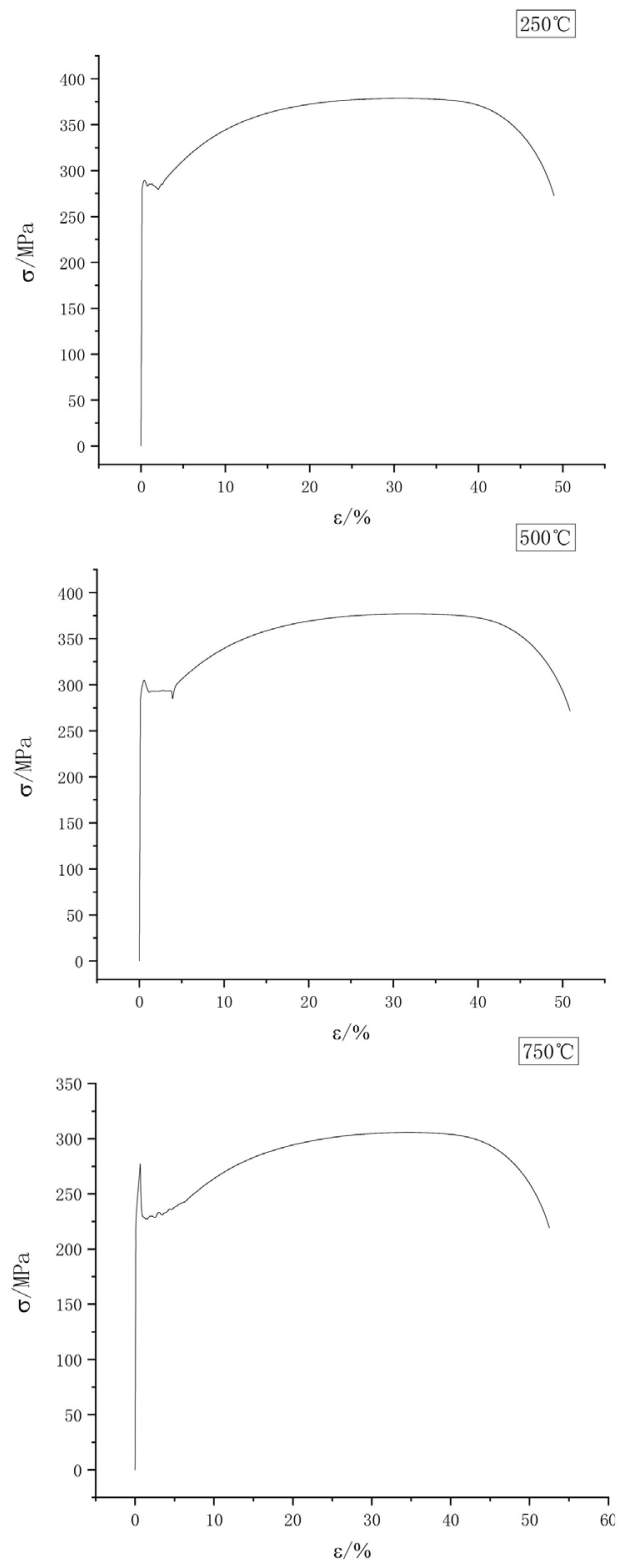

Figure 4. Stress-strain curve of Q345 steel at high temperature. 


\section{Experimental Analysis}

\subsection{Mechanical Properties}

Figure 3 shows the stress-strain curve obtained by the tensile test at room temperature. It has an obvious yield platform with a yield strength of $276.5 \mathrm{Mpa}$ and ultimate strength of $374.5 \mathrm{Mpa}$. Figure 4 shows the stress-strain curve after tensile test. Under the conditions of $250^{\circ} \mathrm{C}, 500^{\circ} \mathrm{C}$ and $750^{\circ} \mathrm{C}$, tensile tests were conducted respectively to obtain the stress-strain curve of steel. It can be seen from Figure 4 that after high temperature, when the stress is small, there is still a period of approximate elasticity, but the yield platform of steel has completely disappeared and there is no obvious yield limit. The yield strength and ultimate strength of Q345 steel at different temperature can be obtained according to the stress-strain relation curve obtained from the test. There is no obvious yield platform for steel at high temperature. Therefore, there is no clear yield strength. Generally, the yield strength of steel at high temperature is determined according to the residual strain or the stress corresponding to a certain mechanical strain.

\subsection{Yield Strength}

Figure 5 shows the curve of material yield strength changing with temperature. It can be seen from the figure that when the temperature is less than or equal to $500^{\circ} \mathrm{C}$, high-temperature cooling has little impact on the yield strength of Q345 steel. Compared with the yield strength at room temperature, the yield strength after cooling at $250^{\circ} \mathrm{C}$ exceeds $2.84 \%$, and at $500^{\circ} \mathrm{C}$, the yield strength exceeds $4.96 \%$ and reaches the peak. When the temperature is greater than $500^{\circ} \mathrm{C}$, the yield strength decreases sharply and reaches the minimum value at $750^{\circ} \mathrm{C}$, which is only $83.59 \%$ of the yield strength of normal temperature steel.

\subsection{Tensile Strength}

Figure 6 reflects the influence of high-temperature cooling on the tensile strength of Q345 steel is similar to the yield strength. The tensile strength gradually decreases with the increase of temperature. When the temperature is less than or equal to $500^{\circ} \mathrm{C}$, the influence of high-temperature cooling on the tensile strength of Q345 steel is not significant, but the strength drops sharply when the temperature is greater than $500^{\circ} \mathrm{C}$. At $250^{\circ} \mathrm{C}$, the tensile strength decreased by $1 \%$, at $500^{\circ} \mathrm{C}$ by $2.07 \%$, and at $750^{\circ} \mathrm{C}$, the tensile strength decreased by more than $20 \%$.

\subsection{Elastic Modulus}

Figure 7 elastic modulus reflects the resistance of steel to deformation. When the steel goes through $200^{\circ} \mathrm{C}-750^{\circ} \mathrm{C}$ high temperature, the elastic modulus of steel is between $2.05 \times 10^{5}-2.25 \times 10^{5} \mathrm{MPa}$, which is quite close to the elastic modulus of steel at room temperature $\left(2.14 \times 10^{5} \mathrm{MPa}\right)$. It can be concluded from the figure that the elastic modulus of the steel varies little with the temperature, so the elastic modulus of the steel after high temperature can be taken as the elastic modulus of the steel at room temperature. 


\subsection{Elongation}

Figure 8 experimental results show that the elongation of Q345 steel is different from other mechanical parameters in that its elongation increases with the increase of temperature: $250^{\circ} \mathrm{C}$ increases by $3.71 \%, 500^{\circ} \mathrm{C}$ increases by $5.4 \%$, and $750^{\circ} \mathrm{C}$ increases by $14.06 \%$.

\subsection{Yield Ratio}

Figure 9 shows that after high temperature cooling, the flexion ratio of Q345 steel first increases and then decreases. At $250^{\circ} \mathrm{C}$, the flexion ratio of Q345 steel increases by $2.82 \%$, by $7.04 \%$ at $500^{\circ} \mathrm{C}$, and by $4.23 \%$ at $750^{\circ} \mathrm{C}$, compared with the normal temperature.

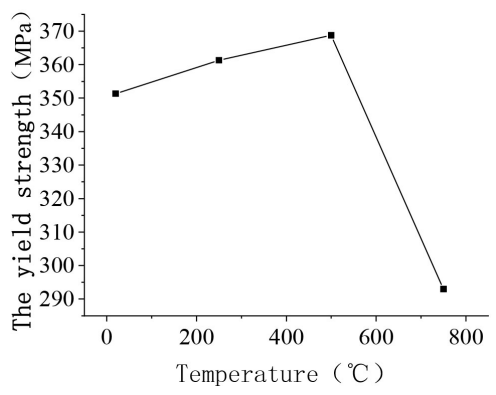

Figure 5. Yield strength.

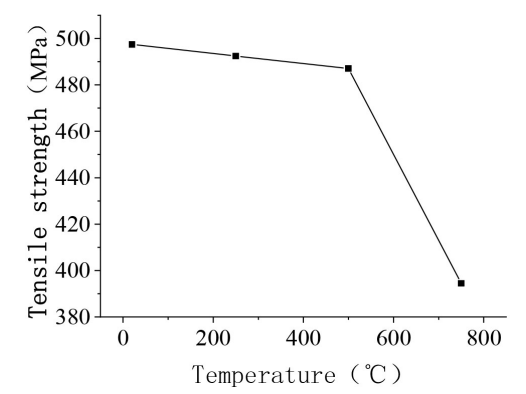

Figure 6. Tensile strength.

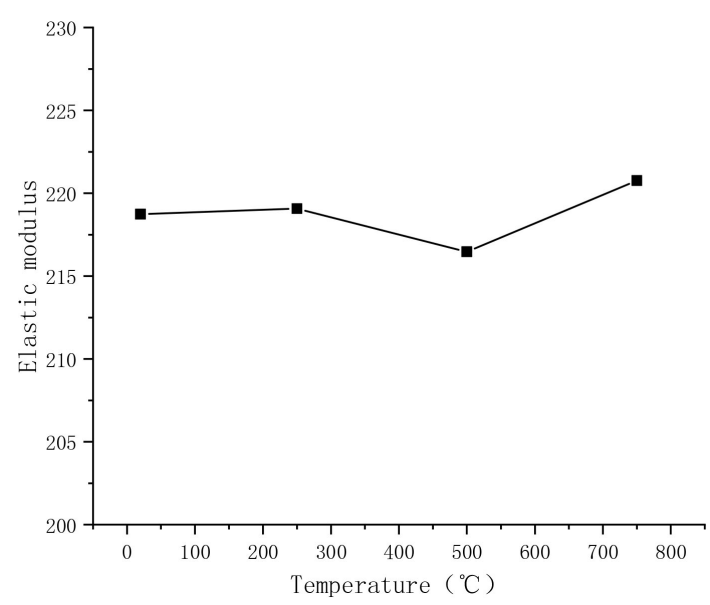

Figure 7. Elastic modulus. 


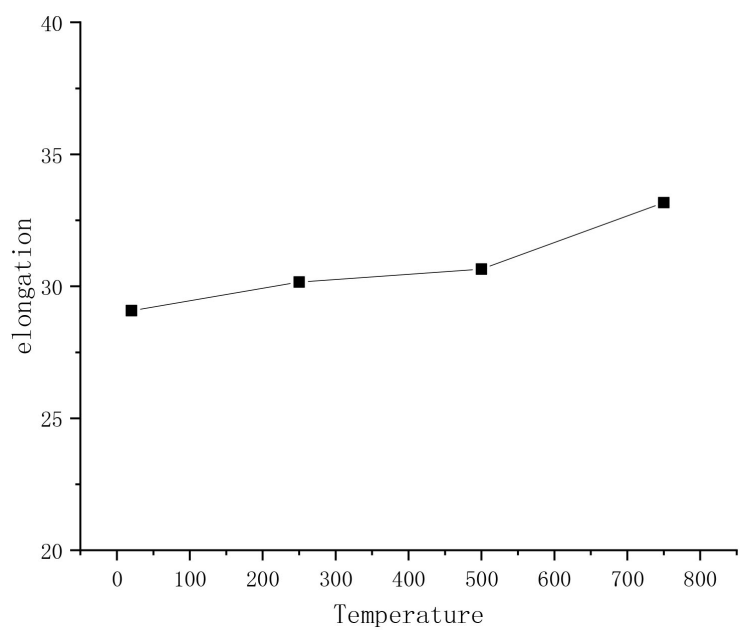

Figure 8. Elongation.

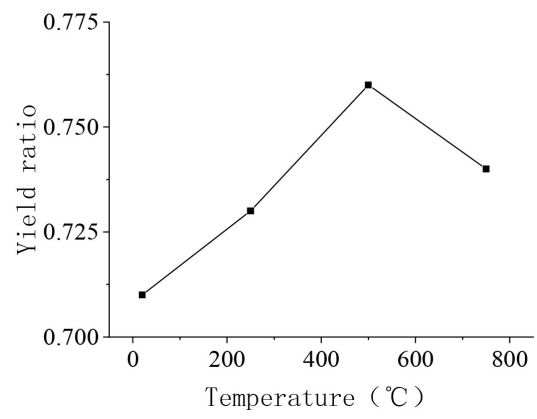

Figure 9. Yield ratio.

\section{Conclusion}

Through the experimental study on the strength and elastic modulus of Q345 steel at high temperature, the following conclusions are obtained. The tensile test of Q345 steel naturally cooled at room temperature $\left(20^{\circ} \mathrm{C}, 250^{\circ} \mathrm{C}, 500^{\circ} \mathrm{C}\right.$ and $750^{\circ} \mathrm{C}$ ) was carried out, and the variation law of the mechanical properties parameters such as stress-strain curve, yield strength, ultimate strength, elastic modulus and elongation with the increase of temperature was obtained. The results show that $500^{\circ} \mathrm{C}$ is the critical temperature at which the mechanical properties of Q345 steel change after natural cooling. Between $250^{\circ} \mathrm{C}$ and $500^{\circ} \mathrm{C}$, the yield strength and tensile strength of Q345 steel changed slightly with the increase of temperature, and the change values did not exceed $5 \%$ of the test value of normal temperature specimen. After exceeding $500^{\circ} \mathrm{C}$, the yield strength and tensile strength of Q345 steel significantly decreased with the increase of temperature. Compared with the test value at room temperature, the yield strength and tensile strength of Q345 steel after natural cooling at $750^{\circ} \mathrm{C}$ decreased by $16.41 \%$ and $20.70 \%$ respectively. The elastic modulus of Q345 steel under high temperature natural cooling basically remains unchanged, and the maximum rate of change is only $1.04 \%$ of the test value at room temperature. At $250^{\circ} \mathrm{C}$ $750^{\circ} \mathrm{C}$, the elongation of Q345 steel increases with the increase of temperature. 


\section{Conflicts of Interest}

The authors declare no conflicts of interest regarding the publication of this paper.

\section{References}

[1] Takeshi, O. and Takeo, A.B.E. (2000) Bucking Strength of Steel Columns Using Fire Resistant Steel (NS FR490A) at High Temperature. Journal of Structural and Construction Engineering (AI), 535, 171-178.

[2] Tan, W. (2000) Study on the Properties of Steel Structure Materials under High Temperature (Fire). Industrial Building, 30, 61-63, 67.

[3] Zhao, J.-C. (2000) Experimental Study on Mechanical Properties of Steel at High Temperature. Architectural Structure, 30, 26-28.

[4] Li, G.Q. and Chen, K. (2001) Experimental Study on Material Properties of Q345 Steel at High Temperature. Architectural Structure, 31, 53-55.

[5] Xu, Y. and Zhao, J.-C. (2004) Experimental Study and Constitutive Relation of Q235 Steel under Different Stress-Temperature Paths. Journal of Shanghai Jiao Tong University, 38, 967-971.

[6] Lv, T.G. (1996) Experimental Study on Strength and Deformation of Steel Reinforcement at High Temperature. Master Thesis, Tsinghua University, Beijing.

[7] Ding, F.X., Yu, Z.W. and Wen, H.L. (2006) Experimental Research on Mechanical Properties of Q235 Steel after High Temperature Treatment. Journal of Building Materials, 9, 245-249.

[8] Qiang, X.H., Jiang, X., Bijlaard, F.S.K., et al. (2016) Mechanical Properties and Design Recommendations of Very High Strength Steel S960 in Fire. Engineering structures, 112, 60-70. https://doi.org/10.1016/j.engstruct.2016.01.008

[9] Wang, W.Y., Liu, T.Z. and Liu, J.P. (2015) Experimental Study on Post-Fire Mechanical Properties of High Strength Q460 Steel. Journal of Constructional Steel Research, 114, 100-109. https://doi.org/10.1016/j.jcsr.2015.07.019

[10] Li, G.Q., Lu, H.B. and Zhang, C. (2017) Experimental Research on Post-Fire Mechanical Properties of Q690 Steel. Journal of Building Structures, 38, 109-116.

[11] GB/T 1591-2008 (2009) High Strength Low Alloy Structural Steels. China Standards Press, Beijing.

[12] GBT 3075-2008 (2008) Axial Force Control Method for Fatigue Test of Metallic Materials. China Standards Press, Beijing.

[13] Qiang, X.H., Bijlaard, F.S.K. and Kolstein, H. (2012) Post-Fire Mechanical Properties of High Strength Structural Steels S460 and S690. Engineering Structures, 35, 1-10. https://doi.org/10.1016/j.engstruct.2011.11.005 